\title{
Rothmund-Thomson syndrome: a case series from a tertiary pediatric hospital in Mexico
}

\author{
Alicia P. Sánchez-Padilla ${ }^{1}$, Adriana M. Valencia-Herrera' ${ }^{1}$ Mirna E. Toledo-Bahena ${ }^{1 *}$, \\ Carlos A. Mena-Cedillos ${ }^{1}$, and Sonia Toussaint-Caire ${ }^{2}$ \\ ${ }^{1}$ Servicio de Dermatología Pediátrica, Hospital Infantil de México Federico Gómez; ${ }^{2}$ Departamento de Dermatopatología, Hospital General \\ Dr. Manuel Gea González. Mexico City, Mexico
}

\begin{abstract}
Background: Rothmund-Thomson syndrome, also known as congenital poikiloderma, is a rare autosomal recessive genodermatosis with onset in early childhood that affects at a multisystem level. Case reports: Case 1. A 4-year-old male patient, consanguineous parents, 26-year-old brother with a probable diagnosis of Rothmund-Thompson syndrome. He presented with adactyly of the right thumb, hypoplasia of the left thumb, delayed growth and psychomotor development. At 3 months, he presented rough, dry, sparse hair and erythematous lesions on the face, leaving hyperpigmented and hypopigmented spots with a reticulated pattern. We detected hypoacusis, skeletal alterations, narrow chin, short stature, severe malnutrition, and chronic and asymptomatic hypodontia. Genetic sequencing showed a mutation for the RECQL4 gene, for which a multidisciplinary follow-up was provided by the genetics, gastroenterology, nutrition, endocrinology, stomatology, audiology, orthopedics, rehabilitation, ophthalmology and oncology services. Case 2. A 2-year-old female patient presented facial erythema that spread to the arms and legs at 3 months; skin biopsy showed poikiloderma. She was evaluated by the endocrinology service and followed up for short stature and hypogonadism. A genetic study was not performed. Conclusions: Rothmund-Thomson syndrome is characterized by atrophy. Only a few cases are reported in the literature. We present two cases of Rothmund-Thomson syndrome, emphasizing its clinical and dermatological characteristics.
\end{abstract}

Keywords: Rothmund-Thomson síndrome. Congenital poikiloderma. Genodermatosis.

\section{Síndrome de Rothmund-Thomson: serie de casos de un hospital pediátrico de tercer nivel en México}

\section{Resumen}

Introducción: El síndrome de Rothmund-Thomson, también conocido como poiquilodermia congénita, es una rara genodermatosis autosómica recesiva de inicio en la infancia temprana y afectación multisistémica. Casos clínicos: Se describen dos casos de pacientes con síndrome de Rothmund-Thomson. Caso 1. Paciente de sexo masculino de 4 años de edad, padres consanguíneos, hermano de 26 años con diagnóstico probable de síndrome de Rothmund-Thompson. Presentó adactilia del pulgar derecho, hipoplasia de pulgar izquierdo, retraso en el crecimiento y retraso del desarrollo psicomotor. A los 3 meses de edad mostraba pelo áspero, seco y escaso, y lesiones eritematosas en la cara, las cuales dejaron manchas

Correspondence:

*Mirna E. Toledo-Bahena

E-mail: mirnatoledo@gmail.com

Available online: $24-01-2022$

Date of reception: 31-01-2021

Date of acceptance: 25-05-2021

DOI: 10.24875/BMHIM.21000013
Bol Med Hosp Infant Mex. 2022;79(1):56-61 www.bmhim.com 1665-1146/@ 2021 Hospital Infantil de México Federico Gómez. Published by Permanyer. This is an open access article under the CC BY-NC-ND license (http://creativecommons.org/licenses/by-nc-nd/4.0/). 
hiperpigmentadas e hipopigmentadas con patrón reticulado. Se detectaron hipoacusia, alteraciones esqueléticas, mentón estrecho, talla baja, desnutrición grave e hipodontia crónica y asintomática. La secuenciación genética resultó con mutación para el gen RECQL4, por lo que se dio seguimiento multidisciplinario por los servicios de genética, gastroenterología, nutrición, endocrinología, estomatología, audiología, ortopedia, rehabilitación, oftalmología y oncología. Caso 2. Paciente de sexo femenino de 2 años de edad que a los 3 meses de vida inició con eritema facial que se diseminó a los brazos y la piernas; la biopsia de piel reportó poiquilodermia. Se encuentra en seguimiento por el servicio de endocrinología por talla baja e hipogonadismo. No se realizó estudio genético. Conclusiones: El síndrome de Rothmund-Thomson se caracteriza por atrofia. Existen pocos casos reportados en la literatura. Se presentan dos casos de síndrome de Rothmund-Thomson, enfatizando sus características clínicas y dermatológicas.

Palabras clave: Síndrome de Rothmund-Thomson. Poiquilodermia congénita. Genodermatosis.

\section{Introduction}

Rothmund-Thomson syndrome (RTS), also known as congenital poikiloderma, is a rare autosomal recessive genodermatosis affecting multiple systems. RTS usually begins in infancy and is characterized by the presence of predominantly facial poikiloderma (telangiectasias, dermal atrophy, hyperpigmented and hypopigmented patches), short stature, sparse hair, dystrophic nails, juvenile cataracts, psychomotor retardation, skeletal abnormalities, premature aging, and predisposition to tumor development, mainly bone. Up to 2001,300 cases have been published worldwide'1.

We present the following case series from the Hospital Infantil de México Federico Gómez.

\section{Clinical cases}

\section{Case 1}

We report the case of a 4-year-old male patient, a native of Tlaxcala, with the following important antecedents: consanguineous parents, 26-year-old brother with a probable diagnosis of RTS. Since birth, the presence of right thumb adactyly, hypoplasia of the left thumb, delayed growth and psychomotor development were reported.

The condition was identified at 3 months of age with the presence of coarse, dry, sparse hair and erythematous lesions on the face, which left hyperpigmented and hypopigmented patches with a reticulated pattern. The patient attended the pediatrics department with impaired hearing, skeletal alterations, narrow chin, short stature, severe malnutrition, and hypodontia.

The dermatology department evaluated the patient for presenting a disseminated dermatosis, including palms and soles, consisting of multiple areas of poikiloderma, telangiectasias, dermal atrophy, hyperpigmented and hypopigmented patches, moderate xerosis of chronic and asymptomatic evolution (Figure 1).

A skin biopsy of one poikiloderma lesion was performed, which reported vacuolar interface dermatitis with epidermal atrophy, pigment detachment, and vascular dilatation (Figure 2). Genetic sequencing of the RECQL4 gene was requested, where the variant was identified in the homozygous state, confirming the diagnosis of RTS.

Photoprotection was indicated every 4 hours and follow-up every 6 months to detect future neoplasms. The patient has no ocular involvement or development of bone tumors or malignant skin lesions and continues in multidisciplinary follow-up by the Genetics, Gastroenterology, Nutrition, Endocrinology, Stomatology, Audiology, Orthopedics, Rehabilitation, Ophthalmology, and Oncology services.

\section{Case 2}

We report the case of a 2-year-old female, a native of Mexico City, with no medical history of importance, who started with facial erythema at 3 months of age, which spread to the arms and legs. The parents took her to a private physician, who referred her to our institution to initiate the diagnostic approach.

The dermatology department evaluated the patient for presenting with a disseminated dermatosis on the head, trunk, and extremities, affecting the cheeks, arms, thighs, and legs, characterized by plaques of poikiloderma (telangiectasias, dermal atrophy, hyperpigmented and hypopigmented patches) with a chronic and asymptomatic evolution (Figure 3). A biopsy of one of the representative lesions showed lamellar hyperkeratosis, areas of hypogranulosis and atrophy, vacuolization of the basal layer, and necrotic keratinocytes. A perivascular inflammatory infiltrates of lymphocytes and histiocytes was found in the papillary 


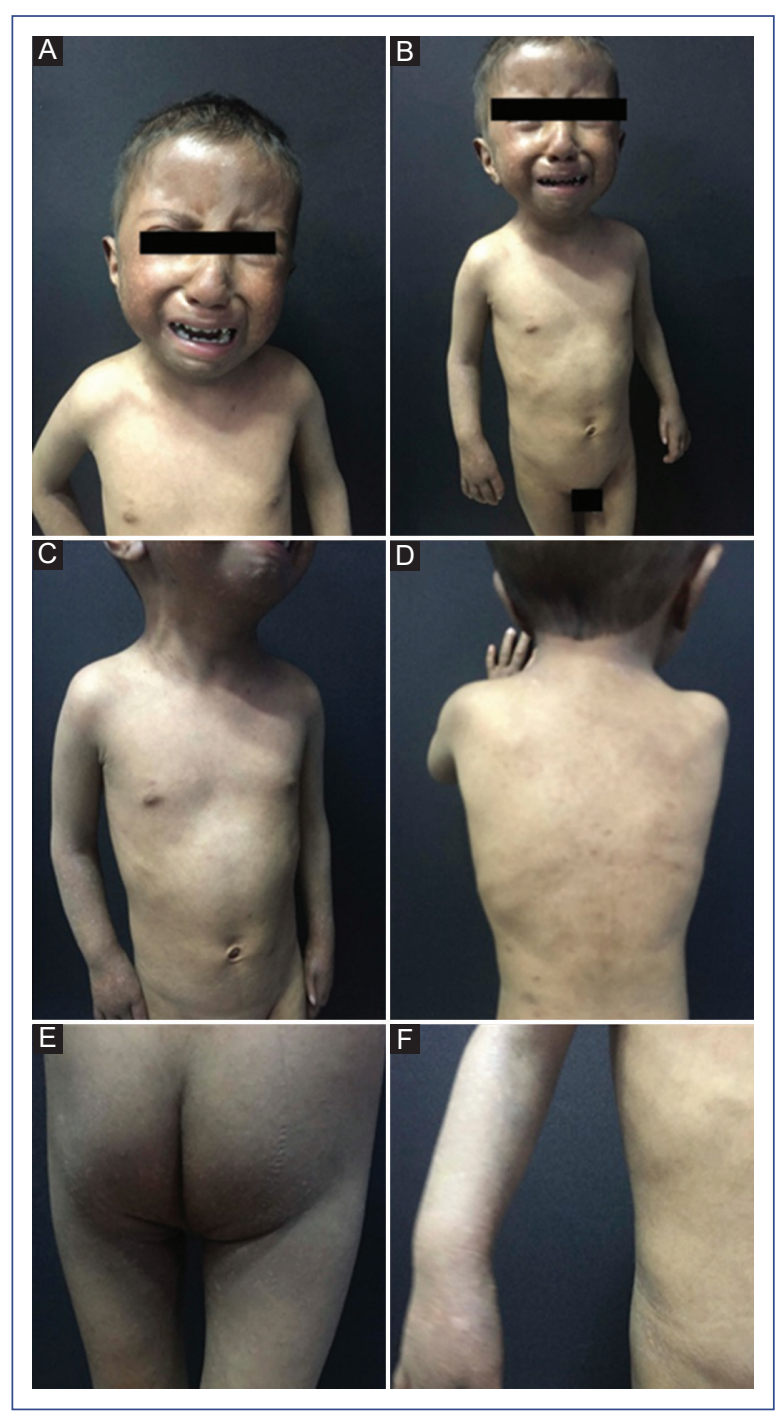

Figure 1. A, B. Facies characteristic of Rothmund-Thomson syndrome, with areas of poikiloderma and telangiectasias on the cheeks. C, D, E. Poikilodermal lesions on the trunk. F. Absence of the thumb.

and reticular dermis, with proliferation and dilatation of blood vessels, pigment deposition, and melanophages. Histological changes were compatible with a poikiloderma lesion (Figure 4). The Orthopedics service evaluated the patient for presenting a spontaneous fracture in the distal metaphysis of the left tibia, which was managed conventionally; the Endocrinology service followed her up for short stature and hypogonadism. To date, the patient does not present cataracts. Unfortunately, a genetic study has not been performed yet. She is currently under strict photoprotection every 4 hours and multidisciplinary follow-up every 6 months.

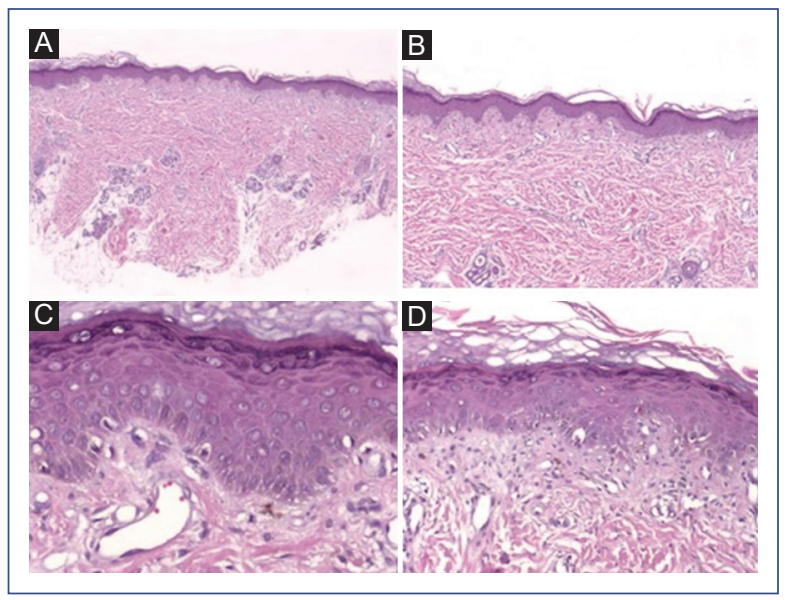

Figure 2. A, B. Histologic section of skin stained with hematoxylin and eosin showing the epidermis with lamellar hyperkeratosis and areas of hypergranulosis. C, D. Areas of atrophy, with vacuolization of the basal layer, individual basal necrotic keratinocytes.

\section{Discussion}

RTS, also known as congenital poikiloderma, is a rare autosomal recessive atrophic dermatosis with few cases reported in the literature. In more than $90 \%$ of patients, symptomatology develops between the third and sixth months of life. It presents with erythematous plaques of reticulated appearance, mild hyperkeratosis, which leave residual hypo- and hyperpigmented patches as they progress, giving the affected area the characteristic appearance of poikiloderma ${ }^{1}$.

This dermatosis was first described by Auguste Rothmund in 1868 and later by Sydney Thomson, a British dermatologist, in 1923. In 1957, William Taylor proposed the eponym RTS, which is how the disease is known today. This disease predominates in males, with a ratio of 2:1. The incidence of RTS in our country is unknown; currently, about 300 cases have been reported worldwide ${ }^{1,2}$.

This syndrome has described two clinical subtypes: type I is characterized by poikiloderma-like lesions, ectodermal dysplasia, and juvenile cataracts; type II is characterized by poikiloderma, congenital bone alterations, and an increased risk of developing osteosarcoma and skin cancer ${ }^{3}$. RTS is transmitted in an autosomal recessive manner and is genetically heterogeneous: subtype I is associated with a mutation in the ANAPC1 gene, and subtype II is caused by homozygous or compound heterozygous mutations in the RECQ-like helicase type 4 (RECQL4) gene, located on 


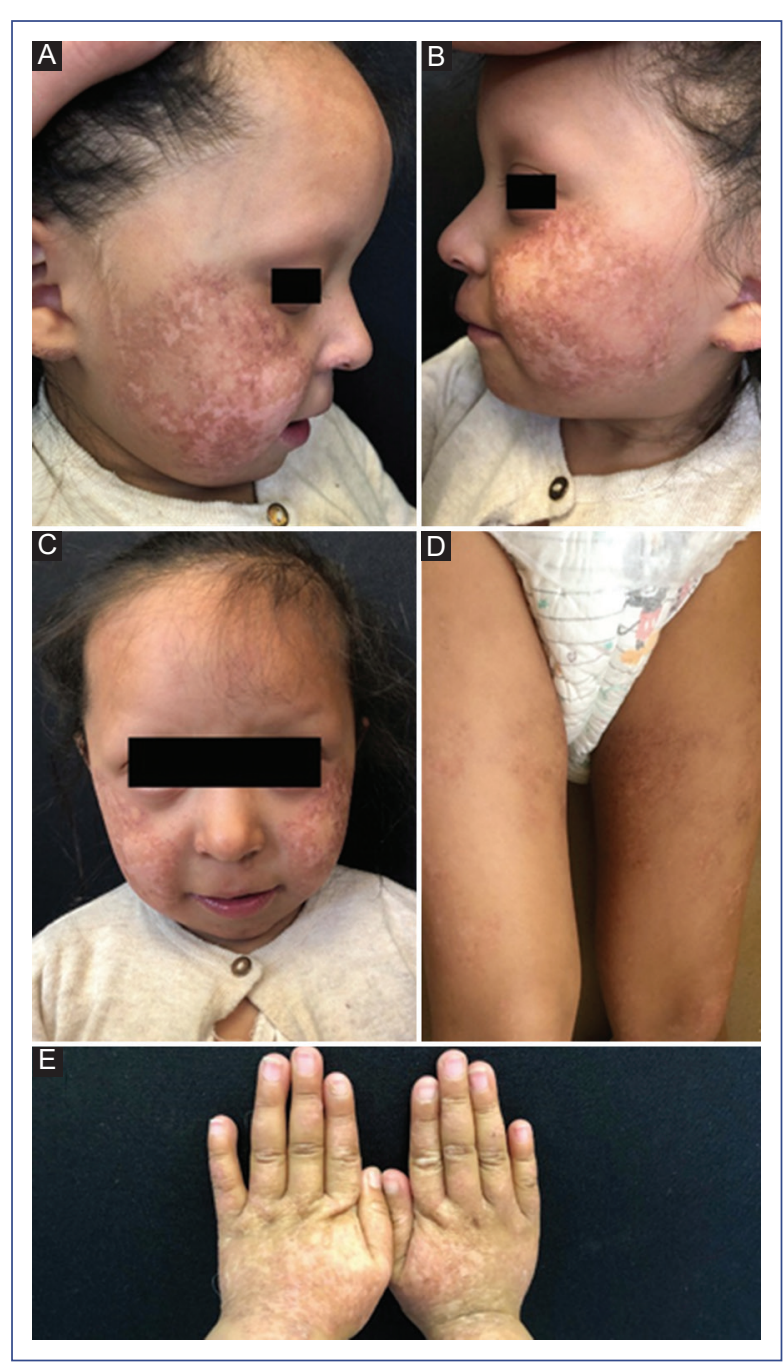

Figure 3. A, B. Poikiloderma lesions: telangiectasias, dermal atrophy, hyper- and hypopigmented spots on the cheeks. C. Facial photosensitivity. D, E. Poikiloderma lesions on the thighs and dorsum of the hands.

chromosome 8q24.3, detectable in approximately $65 \%$ of patients. This gene encodes a DNA helicase involved in DNA repair and replication ${ }^{4}$. In subtype I, the mutations are unknown. This type of mutation increases the risk of developing neoplasms ${ }^{5}$. The reduced DNA repair capacity could be related to the photosensitivity of these patients in early childhood. Although RTS is considered a genodermatosis with multisystem involvement, it is referred to as a chromosomal instability syndrome when mentioning the clinical subtypes ${ }^{3,6}$.

Skin lesions manifest in up to $90 \%$ of patients as facial erythema and edema and vesicles on the cheeks that may extend to the pinnae, forehead, neck, and extremities during the first months of life. As the patient

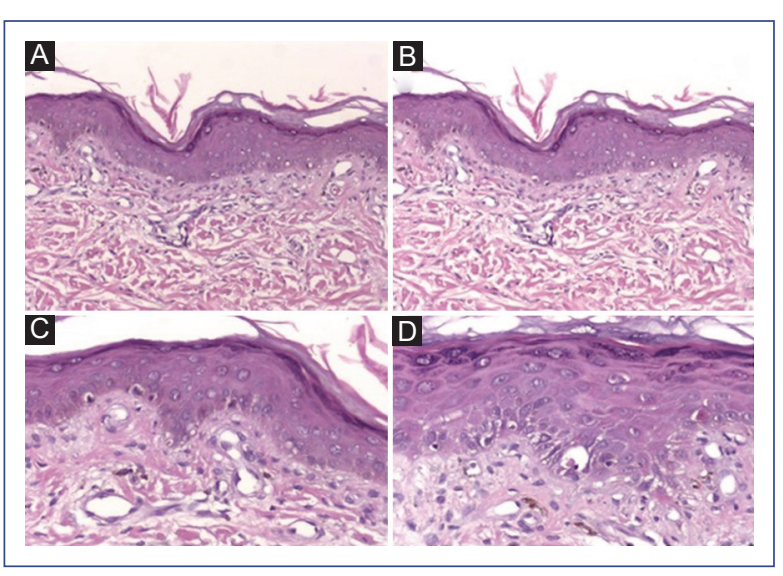

Figure 4. A, B. Epidermis with poikilodermal changes. C, D. In the papillary and superficial reticular dermis, there is a perivascular inflammatory infiltrate of lymphocytes and histiocytes, proliferation and dilatation of blood capillaries, as well as pigment deposits and melanophages.

grows, the characteristic lesions of poikiloderma (telangiectasias, atrophic, hyperpigmented, or hypopigmented plaques) develop and persist for the rest of the patient's life; 30\% may develop palmoplantar hyperkeratosis. Hair and nail manifestations are observed in $30 \%$ of cases, mainly with fine, thin, and sparse hair, development of premature graying, areas of alopecia, and dystrophic nails or anonychia?.

Photosensitivity occurs in $30 \%$ of patients and can trigger blistering lesions. Warty keratoses may develop in photo exposed areas, which in the long term may develop skin cancer (basal cell carcinoma being the most common), including melanoma by the age of 20-30 years. Other neoplasms associated with RTS are hematologic, gastrointestinal, and osteogenic sarcomas $^{6,7}$. Some manifestations associated with RTS are short stature, dental hypoplasia, and hypogonadism; patients may present with cataracts, coloboma, or keratoconus at an early age. In most cases, mental development is normal 8,9 .

The skeletal malformations described in these patients are bone shortening, predisposition to fractures, metaphyseal growth arrest, dysplastic changes in the phalanges, hypoplasia of the bones of the forearm or thumb, and hypoplasia or absence of the patella. These manifestations taken together can guide the diagnosis. The most dramatic association is osteosarcoma, which only occurs in RTS patients with RECQL4 mutations ${ }^{10,11}$.

Table 1 describes the main manifestations of RTS and their frequency of presentation and Table 2 lists the manifestations found in our case series. 
Table 1. Main manifestations of Rothmund-Thomson syndrome*

\begin{tabular}{|c|c|}
\hline Clinical manifestations & Percentage \\
\hline $\begin{array}{l}\text { Skin } \\
\text { - Erythema and facial edema, in early ages, } \\
\text { evolving to poikiloderma changes: atrophy, } \\
\text { telangiectasias, hyperpigmentation, or } \\
\text { hypopigmentation } \\
\text { - Photosensitivity, blistering } \\
\text { - Hyperkeratosis on hands, feet, knees } \\
\text { - Calcinosis cutis, actinic keratosis }\end{array}$ & $90 \%$ \\
\hline $\begin{array}{l}\text { Hair } \\
\text { - Fine, sparse, progressing to partial or total } \\
\text { alopecia, absence of eyebrows and eyelashes }\end{array}$ & $30 \%$ \\
\hline $\begin{array}{l}\text { Nails } \\
\text { - Nail dystrophy, anonychia }\end{array}$ & $30 \%$ \\
\hline $\begin{array}{l}\text { Dental disorders } \\
\text { - Caries, microdontia, conical teeth }\end{array}$ & $40 \%$ \\
\hline $\begin{array}{l}\text { Skeletal alterations } \\
\text { - Saddle nose, prognathism, agenesis of } \\
\text { carpus and thumb, syndactyly, osteogenesis } \\
\text { imperfecta, hyperostosis, osteoporosis }\end{array}$ & $70 \%$ \\
\hline $\begin{array}{l}\text { Ocular alterations } \\
\text { Cataracts, keratoconus, coloboma, } \\
\text { strabismus, amblyopia, microphthalmia, optic } \\
\text { nerve atrophy, exophthalmos, glaucoma, } \\
\text { photophobia, hypertelorism }\end{array}$ & $50 \%$ \\
\hline $\begin{array}{l}\text { Neoplasms } \\
\text { - Osteosarcomas, basal cell carcinoma, } \\
\text { squamous cell carcinoma, melanoma, } \\
\text { fibrosarcoma, lymphoma, gastric carcinoma, } \\
\text { myelodysplastic syndrome, acute myelocytic } \\
\text { leukemia. }\end{array}$ & $3-32 \%$ \\
\hline $\begin{array}{l}\text { Others } \\
\text { - Low birth weight, growth retardation, short } \\
\text { stature, hypogonadism }\end{array}$ & $20-50 \%$ \\
\hline
\end{tabular}

Diagnosis is clinical and is confirmed with a molecular study to detect the RECQL4 gene mutation; however, access to this study can be limiting ${ }^{12}$.

Histopathology analysis showed poikiloderma, hyperkeratosis, epidermal atrophy, basal vacuolar change, rare apoptotic keratinocytes in the basal layer, numerous telangiectatic vessels, scattered dermal melanophages, and a variable infiltrate of upper dermal inflammatory cells $\mathbf{s}^{13,14}$.

The differential diagnosis should be conducted with other pathologies, such as Cockayne syndrome, trichothiodystrophy, congenital dyskeratosis, Fanconi anemia, Bloom syndrome, and poikiloderma with neutropenia. However, other diseases may present the same dermatologic features, as in systemic lupus erythematosus, which may obscure the diagnosis ${ }^{15-17}$.
Table 2. Clinical differences between patients with Rothmund Thomson syndrome

\begin{tabular}{|l|l|l|}
\hline Clinical manifestations & Case 1 & Case 2 \\
\hline Facial erythema & Absent & Present \\
\hline Poikiloderma & Present & Present \\
\hline Photosensitivity & Present & Present \\
\hline Hyperkeratosis & Absent & Absent \\
\hline Actinic keratosis & Absent & Absent \\
\hline Hair disorders & Present & Absent \\
\hline Nail disorders & Present & Absent \\
\hline Ocular alterations & Absent & Absent \\
\hline Dental alterations & Present & Absent \\
\hline Skeletal alterations & Present & Present \\
\hline Neoplasms & Absent & Absent \\
\hline Short stature & Present & Present \\
\hline Hypogonadism & Absent & Present \\
\hline Hearing loss & Present & Absent \\
\hline Malnutrition & Present & Absent \\
\hline
\end{tabular}

The management of these patients focuses on multidisciplinary follow-up and genetic counseling for early identification of the manifestations associated with the syndrome, thus maintaining strict surveillance to detect the development of possible neoplasms ${ }^{18,19}$.

The management of dermatologic lesions consists of avoiding ultraviolet radiation and strict photoprotection. Currently, it has been shown that telangiectatic lesions in these patients respond favorably to pulsed dye laser treatment. When malignant tumors do not develop, life expectancy is normal ${ }^{20,21}$.

The prognosis is limited to the occurrence of malignant neoplasms; however, there are reports of patients over 50 years of age ${ }^{22}$.

In this report, we emphasize the clinical and dermatologic characteristics of RTS. We have identified two patients diagnosed with RTS in the Hospital Infantil de México Federico Gómez, making this series the first case series reported in our country. From the dermatological point of view, it is essential to maintain strict surveillance of these patients since they are at higher risk of developing cutaneous neoplasms, such as basal cell carcinoma, squamous cell carcinoma, and, less frequently, melanoma. It is, therefore, necessary to implement photoprotection measures and avoid 
ultraviolet radiation from the early stages of life, which will increase the life expectancy of these patients.

\section{Ethical disclosures}

Protection of human and animal subjects. The authors declare that no experiments were performed on humans or animals for this study.

Confidentiality of data. The authors declare that they have followed the protocols of their work center on the publication of patient data.

Right to privacy and informed consent. The authors have obtained the written informed consent of the patients or subjects mentioned in the article. The corresponding author has this document.

\section{Conflicts of interest}

The authors declare no conflict of interest.

\section{Funding}

None.

\section{Acknowledgments}

We thank the patients of the Hospital Infantil de México Federico Gómez for being our most outstanding teachers.

\section{References}

1. Wang LL, Levy LL, Lewis RA, Chintagumpala MM, Lev D, Rogers $M$, et al. Clinical manifestations in a cohort of 41 Rothmund-Thomson syndrome patients. Am J Med Genet. 2001;102:11-7.

2. Silverberg NB, Biro DE, Laude TA. What syndrome is this? Rothmund-Thomson syndrome (poikiloderma congenitale). Pediatr Dermatol. 1999;16:59-61.
3. Larizza L, Roversi G, Volpi L. Rothmund-Thomson syndrome. Orphanet J Rare Dis. 2010;5:2.

4. Ajeawung NF, Nguyen TTM, Lu L, Kucharski TJ, Rousseau J, Molidperee S, et al. Mutations in ANAPC1, encoding a scaffold subunit of the anaphase-promoting complex, cause Rothmund-Thomson syndrome type 1. Am J Hum Genet. 2019;105:625-30.

5. Lindor NM, Furuichi Y, Kitao S, Shimamoto A, Arndt C, Jalal S. Rothmund-Thomson syndrome due to RECQ4 helicase mutations: report and clinical and molecular comparisons with Bloom syndrome and Werner syndrome. Am J Med Genet. 2000;90:223-8.

6. Wu J, Capp C, Feng L, Hsieh TS. Drosophila homologue of the Rothmund-Thomson syndrome gene: essential function in DNA replication during development. Dev Biol. 2008;323:130-42.

7. Lu L, Jin W, Liu H, Wang LL. Aging in Rothmund-Thomson syndrome and related RECQL4 genetic disorders. Ageing Res Rev. 2017;33:30-35.

8. Lu L, Jin W, Wang LL. RECQ DNA helicases and osteosarcoma. Adv Exp Med Biol. 2020;1258:37-54.

9. Sangrithi MN, Bernal JA, Madine M, Philpott A, Lee J, Dunphy WG, et al. Initiation of DNA replication requires the RECQL4 protein mutated in Rothmund-Thomson syndrome. Cell. 2005;121:887-98.

10. Simon T, Kohlhase J, Wilhelm C, Kochanek M, De Carolis B, Berthold F. Multiple malignant diseases in a patient with Rothmund-Thomson syndrome with RECQL4 mutations: case report and literature review. Am J Med Genet A. 2010;152A:1575-9.

11. Piquero-Casals J, Okubo AY, Nico MM. Rothmund-Thomson syndrome in three siblings and development of cutaneous squamous cell carcinoma. Pediatr Dermatol. 2002;19:312-6.

12. Kumar P, Sharma PK, Gautam RK, Jain RK, Kar HK. Late-onset Rothmund-Thomson syndrome. Int J Dermatol. 2007;46:492-3.

13. Gupta S, De S, Srivastava V, Hussain M, Kumari J, Muniyappa K, et al. RECQL4 and p53 potentiate the activity of polymerase and maintain the integrity of the human mitochondrial genome. Carcinogenesis. 2014;35:34-45.

14. Green JS, Rickett $A B$. Rothmund-Thomson syndrome complicated by osteosarcoma. Pediatr Radiol. 1998;28:48-50.

15. Colsante MV, Gómez ML, Valente EE, Cabrera HN, García SA. Síndrome de Rothmund-Thomson, poiquilodermia congénita. Arch Arg Dermatol. 2002;52:153-8.

16. Arnold AW, Itin PH, Pigors M, Kohlhase J, Bruckner-Tuderman L, Has C. Poikiloderma with neutropenia: a novel $\mathrm{C} 16$ orf57 mutation and clinical diagnostic criteria. Br J Dermatol. 2010;163:866-9.

17. Yang JY, Sohn YB, Lee JS, Jang JH, Lee ES. Rare presentation of Rothmund-Thomson syndrome with predominantly cutaneous findings. JAAD Case Rep. 2017;3:172-4.

18. Ciloglu S, Duran A, Pekcan SY, Buyukdogan H. Leg ulcer in a patient with Rothmund-Thomson syndrome. Springerplus. 2015;4:572

19. Yves Sznajer H, Siitonen A, Roversi G, Dangoisse C, Scaillon M, Ziereisen $F$, et al. Atypical Rothmund-Thomson syndrome in a patient with compound heterozygous mutations in RECQL4 gene and phenotypic features in RECQL4 syndromes. Eur J Pediatr. 2008;167:175-81.

20. Romero Flórez A. Síndrome de Rothmund-Thomson o poiquilodermia congénita. Dermatol Rev Mex. 2012;56:354-7.

21. Ruiz VR, Corral A, Sánchez CD, Sánchez-Lafuente FJP. Síndrome de Rothmund-Thomson. An Pediatr. 2005;63:271-2.

22. Potozkin JR, Geronemus RG. Treatment of the poikilodermatous component of the Rothmund-Thomson syndrome with the flashlamp-pumped pulsed dye laser: a case report. Pediatr Dermatol. 1991;8:162-5. 